\title{
Man-World Relationship in the Landscapes of B.Ia. Riauzov
}

\author{
Maya G. Smolina*, \\ Anastasia N. Tamarovskaya, Daria V. Smirnova, \\ Natalia A. Fedoriako, Marina A. Legkova, \\ Larisa N. Vergeichik and Alexandra I. Tat'ianina \\ Siberian Federal University \\ 79 Svobodny, Krasnoyarsk, 660041, Russia
}

Received 18.11.2014, received in revised form 28.12.2014, accepted 21.01.2015

This paper analyzes the relationship of man and the world in the picturesque landscapes of the Krasnoyarsk painter B.Ia. Riauzov. The authors consider two basic philosophical issues, reflected in the work of the Siberian artist, i.e. conflict between "nature" (also first nature) and "culture" (second, man-made nature), idyllic relationship between man and the world.

Keywords: painting, Krasnoyarsk, Siberia, Boris Iakovlevich Riauzov, relationship of man and the world, landscape, socialist realism, the Great Patriotic War, horizontal composition, urban landscape, existential problems.

Research area: culture studies, art history.

\section{Introduction}

Style, which is prominent in the paintings of outstanding creative Krasnoyarsk master of landscape Boris Iakovlevich Riauzov (1919-1994), is called socialist realism. Emotional impasto enjoyed a certain degree of freedom in the Soviet era. It is kind of dramatization of the birth of the second reality from the colorful surface, preserving the form of thick brush strokes. This manner of painting forces the process of fighting between the brush stroke and that second reality, conveyed by this stroke, i.e. this is the struggle between artistic material and artistic form.

Creativity of Krasnoyarsk artist B.Ia. Riauzov is represented in the genre of landscape. In the epoch complex for art due to the Soviet ideology this genre gave a lot more freedom for creative activity than any other. Besides, landscape is a traditional genre for Siberian school as it is. Following the tradition of his teacher D.I. Karatanov Boris Riauzov was solving the problem of determining by the Siberian man their own place in the world in depicting the native and vast homeland of Siberia.

On the canvases of Krasnoyarsk master on the display in the B.Ia. Riauzov museum's permanent exhibition (Krasnoyarsk) there are two main and modeled philosophical problems: the conflict between "nature" (first nature) and

C) Siberian Federal University. All rights reserved

* Corresponding author E-mail address: smomg@yandex.ru 
"culture" (second nature), idyllic relationship between man and the world.

\section{Culture and nature}

The juxtaposition of nature and culture as a conflict of human existence in the godless world, in a kind of desert of atheistic existence, and the situation of mutual repulsion of the material and the spiritual are characteristic for dramatic "war landscapes" of Boris Iakovlevich Riauzov, who became involved in exhibitions in very 1941. Being at the front, the artist participated in creative work to the possible extent by creating works with existential content, the feeling of abandonment in the human world, the aesthetics of the "lost generation".

His watercolor landscape This Was the Novorzhev City. It Was Murdered and Plundered by the Germans, made in 1945 [see May Waltz], influences effectively the viewer's emotions with the help of verbal communication: the virtual entrance to the space of the landscape is a table with the words, which are rendered in the title of the work. The inscription points out indicatively that this is a former city, a city that no longer exists, having stopped being a reality, a ghost city. The chosen technique - watercolor emphasizes the illusory transparency, mirage of remaining buildings and ruins. "The place for the spectator" is on this road going to the city mirage, on the road which runs away and hides behind the ruins. On the road there is a figure of a walking towards the viewer man. In the background there are a church (a building with a dome) and a twostorey building with a destroyed roof. The sky is light, with pale patches of diffused clouds. The background is the landscape ruins, located between the church and a sign with the words "This Was the Novorzev City...”. By extrapolating the specifics of this watercolor landscape to historical events we find that on July 17, 1941 Novorzhev (in Pskov Oblast') was occupied by Nazi troops and released on February 29, 1944. Pskov Oblast' is inconceivable without the churches, so that is probably why the image of the church can be thought as documentary. But this church is not an accidental sign in the space of the artistic whole, as the return to faith in God is typical during such a social cataclysm as a war.

A pillar, which bears the sign with inscription, is visually continued in a vertical wall behind it and a high spruce. The crumbling wall is generally a pyramid, this pyramid benching is also supported by the increasing height of trees. There is a kind of triangular composition in the destroyed; spiritual victory as a triumph, a win of victory is paradoxically given in the ruins of the city even if such was the cost for this victory. This view embodies the price of spiritual victory - through the destruction of the flesh, and large material losses are a kind of an eternal monument-altar.

The architecture in this work is a landmark for destructive and creative human activity. Nature is shown as deserted space with poor vegetation, cool skies and the "soaring" to heaven through steps-firs road. Nature stresses destructiveness, produced by man, and invites people to think about the eternal, Absolute, to make up for the lost relationship with God.

Next war watercolor of B.Ia. Riauzov containing existential questions is On Roads of Smolensk [see May Waltz]. In this work there are no significant vertical line, there are only horizontal lines of the sky and ground, as if they are separate, unrelated layers of existence. There are corpses lying along the creeping curve of the road. The vertical lines are weak and restrained: trees are slightly visible behind the hills, only their tops are discernible, so that nothing builds a strong relationship with the sky. The sky is cold, white and blue, which is a metaphor for the cruelty and indifference of the world. Bodies of the dead soldiers along the 
roadside are painted in earthy colors, they almost dissolve to the colour of the ground, combining with it in organic whole. This gives an idea that traces of these deaths will soon be erased, transformed into the desert landscape, the land will take them and decompose, that is the harsh reality of the world. This watercolor was created from the existential point of view related to the test of man in the face of death, and inspired by the fact that the road goes past in spite of the bodies on roadsides. The picture reveals that the sky has not asked the person if he would want to live in this world, the man has been thrown into this world, and the world is not responsible for him now. In the distance one can see the trucks, seemingly taking the corpses away for burial. It also shows the society functioning mechanism, so the society takes care of fallen soldiers, laments them, but the role of this care itself is insubstantial (not important) to them, that is why the trucks are painted too far, almost invisible. The road, on which spectators find themselves virtually, directs their glances in some misty distance of uncertainty, dodging between the results of the war. The idea of work is an ordeal whether to be a participating spectator or an indifferent human (provocative alternative to "pass by without noticing").

Nature in the image recedes into the background, being shown in the wilderness of the land and the sky, in the cold of the sky, in the muddy ground and silent trees, creating scenery for the final "silent" stage of the theater of war.

B.Ia. Riauzov's works showing war continue the traditions of Russian culture connected with mourning the consequences of war, its meaningless crops in the form of death. Lament and grieve from this loss are deeply rooted national phenomena, however, these works also convey a state of spiritual desolation and helplessness of man in front of the realities of the world, which brings existential sensitivity.
The painting The Riverboats was made by B.Ia. Riauzov in 1951 [see All that is in the Heart]. The riverboats are presented in a clear geometric composition, characteristic of the "Stalinist classicism" style. In this work we can see vertically balanced contours, which are not typical for predominantly "horizontal" Riauzov's landscapes. Clear vertical and horizontal lines belong to the boat as to the product of the human mind and hands, built in a clear system of coordinates, while the surface of the river is silent in obedience to human culture, the sky is cold-detached in tolerating smoke and is pierced by sharp masts. Thus, we can say that this picture, painted in Stalin's time, reflects equal and belligerent attitude-conflict between human cultural and creative activities and the universe with natural indifference.

B.Ia. Riauzov's painting A New Town. The Past Goes by (1982) is primarily characteristic for the creativity of Krasnoyarsk master in socialist realism. The work is a landscape of urban type having predominantly horizontal orientation. At first glance it may seem that what is within the artistic space is nothing more than a sketch, sliceof-life of a certain part of the city. However, it is also possible to observe features, characteristic of the entire work of the painter: the picture contains also some philosophical reflections on life in the city.

The revival of urban space, the artist's perception of it as a living organism can be traced in the very name of the picture. The town is endowed with the signs of action inherent in all living things, where something is renewed and something old is sacrificed. Having looked at the title, the viewer sees all the elements of the artistic image in their independence and integrity. Indeed, the artful scenery can bare a clear distinction between two parts - the new town, represented by a slender row of numerous high buildings and the old town, manifested in the form of several 


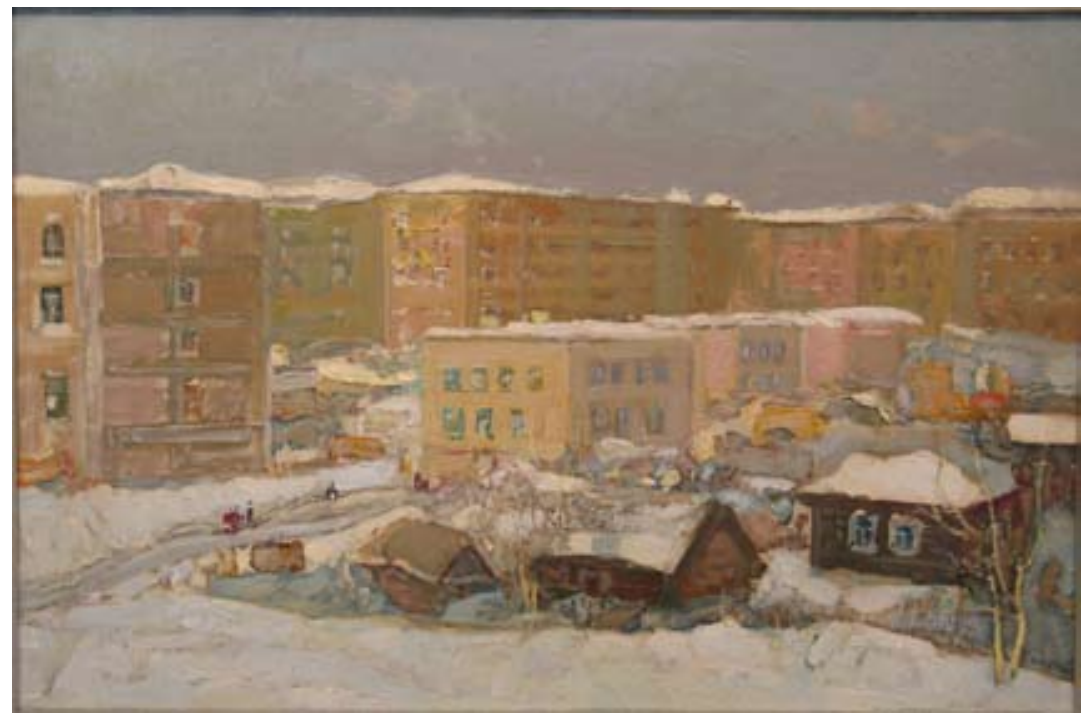

Pic. 1. Boris Riauzov. A New Town. The Past Goes by (1982)

low wooden houses. The juxtaposition of two parts is shown in their disposition, the area of The New Town literally covers a large part of the artistic image, the old part is restricted to one corner only. We can say that brick skyscrapers form the perspective, pointing out that this is the area of the future. Thus, the first step in dealing with the artwork is that the spectator absorbs the documented fixation of the new town growth practically on the ruins of the old, which will soon disappear altogether.

However, a more detailed examination of all elements contributes to a change of emphasis in contrasting two parts of the work. Referring to the large space under construction of modernity one can see that B.Ia. Riauzov shows all the houses forming this modernity as uniform and looking the same. Hard lines, clear contours contribute to the perception of new buildings as original boxes, some parts of them even have windows cut through, but they are very poorly distinguishable. The only difference between all these "boxes" is their colour. Perhaps this can be seen as creating the effect of comfort and joy of life, manifested only in the external side, whereas inside has indifference and callousness. The old part is in contrast more active and represented more lively. First of all, this stroke of life is read on the material level already, where a lively texture is created by literally playing strokes contrasted with the smoothness and monotonous way of organizing colour forms in the new part of the town. In addition, while the new skyscrapers are built in a structured system where the dominant concepts are lines and geometric organization, the location of the houses in the old part of the town is freer, which increasingly helps their association with naturalness. Closeness to nature is obvious in the presence of natural elements such as trees, in interconnection with houses, recalling that it is a living tree which is the material to make these houses. One can draw an analogy between the trees sprouting from the snow-covered ground and the wooden dwellings, which naturally sprout from the ground along with the trees. Important characters are the people walking on the road separating the two parts of the picture. However, the direction of their movement is easily detectably, they all go to the new part of the town, passing the old one. 
Comparing all results derived from the analysis of elements of the artistic image, you may find that the initial impression of the documentary fixation of the town transformation is gradually supplemented by the painter's attitude to the processes, as well as by philosophical reflection of some kind, which is expressed in the awareness of the outgoing and completely forgotten natural comfort in favor of the progress. Thus, the old part of the town is concealed in terms of intimacy with nature, while the new part represents an increasing distance from nature.

\section{Idyll}

The Riauzov's work has both the thesis of conflict between human existence and the world and the antithesis about their harmonious relationship with each other. The works mentioned in the first part of the paper can be compared with their complete opposites. For example, the aforementioned painting The Riverboats of 1951 may be contrasted with another water landscape The Boat Station of 1972-1973. The painting of the "boat station" represents one of the most interesting places in Krasnoyarsk, having now lost its former popularity. A large number of multi-colored boats are moored along the quay. One of them, cutting the surface of the river, is a bit further. Strolling along the beach people are look at a pier and are passing to the boats. These movements do not have the hustle and hurry, they are little drawn and visible only in general outlines and silhouettes.

Nature (mountains, trees) surrounding the quay is calm and monumental, and despite the apparent wave the water surface has a smooth surface, reflecting the sky and colorful boats. Mountain ranges look majestic, the sky looks cold, and the coast looks steep. All nature reveals inherent inaccessibility and majesty. Here everything is in harmony and unity, people can only be built into this system, adapting to its conditions and contemplating its greatness. Human dwellings do not cross the forms of the mountains, they do not seek to go beyond their forms, they are lined up all and the same, and their rhythm is echoed in the rhythm of the mountainous terrain.

Perhaps, this painting renders about the uniqueness of the location of the city of Krasnoyarsk and its nature, its participation in the natural process. The tranquility of the Yenisei

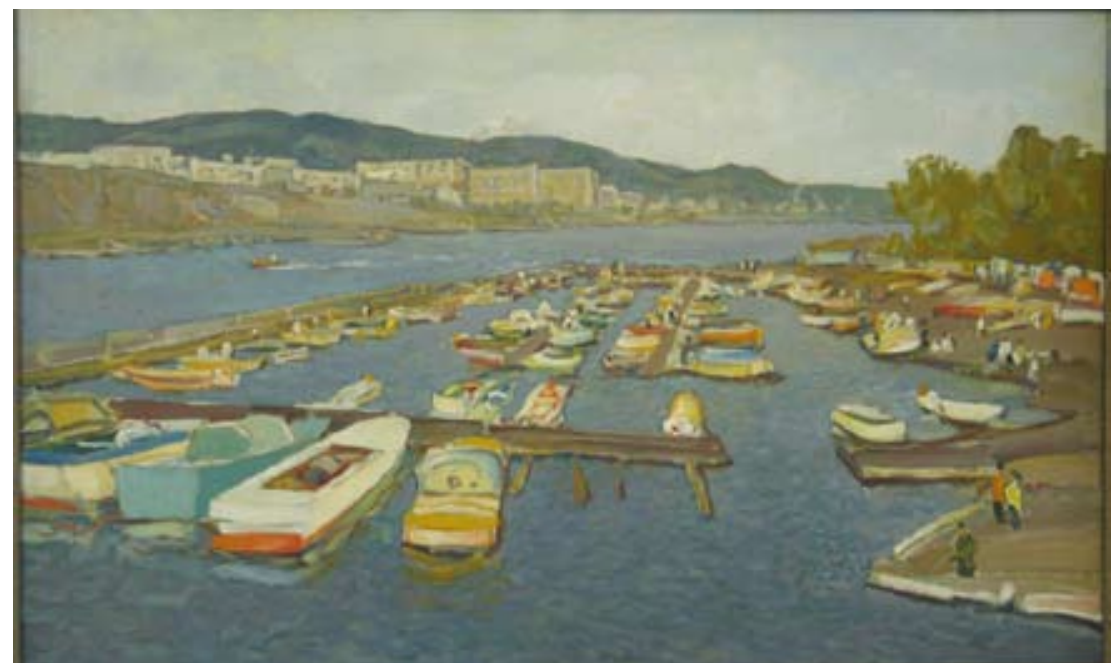

Pic. 2. Boris Riauzov. The Boat Station (1972-1973) 
and cold mountains create a sense of unshakable harmony that fills the entire space. People could feel their closeness to nature, meditating on its pristine natural order.

The most colorful and bright spots are boats on the dock, made in the manner reminding Impressionism. Broad brushstrokes of local color create a colorful pattern of the boats in the eye of the viewer. However, this manner is not repeated in painting the other elements of the picture. Mountains, sky, green trees are made in a more generalized manner and in cold tones. Water barely reflects boat shades and there is no chatoyment play of colors, glare and light. This suggests that the artist, having mastered impressionistic method although, did not copy it completely, but only added some basic techniques to his manner having been developed by this time.

There are traits that characterize the work of the late period of the artist: the unity of heaven, space mountain and water; human embeddedness in the system, the romanticizing of the urban landscape. Thus, the work represents the artist's creativity of 1970 s as they belong to the stylistic space called "areaclassicizm". You can learn more about stylistic spaces "areaclassicizm" and "arearomantizm" from the writings of V.I. Zhukovskii ("Theory of Fine Arts") [Zhukovskii]. In this case, this concept reflects the explanatory attitude towards the world of the artist, whose function is to expose the boundaries and structure of the universe in their clarity, isolation, bulk (instead of vague, obscure, plain) form. B.Ia. Riauzov seeks to grasp the world intellectually, presenting how nature dictates its rules, and man as beings subordinate to it, open to relations with it, receptive and energetically taking its gifts. People on the beach and boats which dot the shore are perceived by the artist as a manifestation of the love-mutual attraction of natural and cultural origins.

Intimate, modest and touchingly lyrical The Winter Motive (1970) is an idyllic relationship of man and the world, in contrast to the painting $A$ New Town. The Past Goes by of 1982, discussed above as an example of the conflict of alternatives

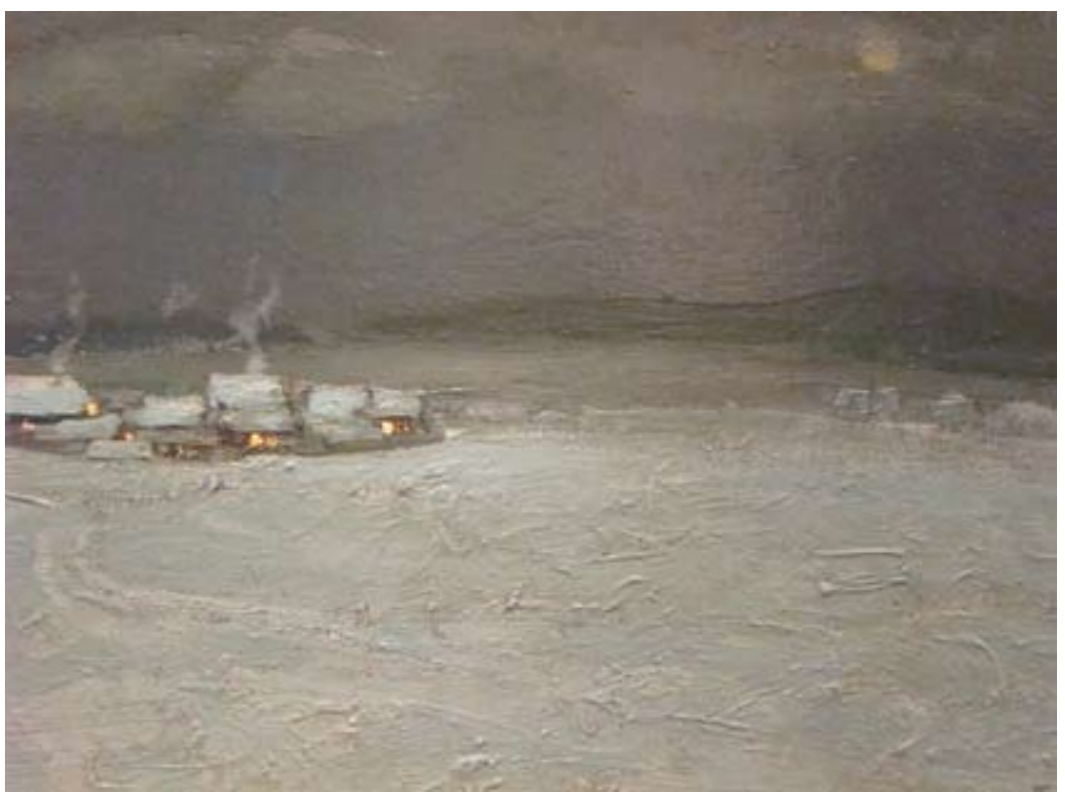

Pic. 3. Boris Riauzov The Winter Motive (1970) 
"closeness to nature" and "the culture of the newly formed".

In The Winter Motive small village huts at night are shown as thickly covered with snow. The higher we look the more transparent and weightless the strokes become, and the story turns into a plot of painting: you notice not the paint, but a real smoke rising from the chimneys to the sky, and there one can see clouds of frosty mist, which wrap up the moon with a blanket, making it almost invisible.

The dark mountains rise on the horizon in tiers, as if growing out of snow - it is like speed color film changing from the color of snow to the color of the sky, connecting two opposite in reality, but related, and even common worlds, the earth and heaven worlds are united in one work. This is emphasized even in the color of houses' roofs, they are the same as the sky to a nicety. The unity of the earth and heaven worlds blurs the structure of the world, raising the terrestrial world and grounding the celestial one.

Dissolution of the colours from the lower part of the work to the upper one and from the bottom up is expressed not only in the color unity, the gradual reduction and thinning, weightlessness strokes' change from pasty to heavy glazing, but also in the images of such phenomena as smoke and fog, which are light, floating and transparent.

Thework has several uniqueburning beacons, especially engaging the viewer's attention, these are "the characters" of lights in the windows and the moon. Human and natural origins are identical, each of them is appealing, prominent in a total depth of the night. The windows' lights are warm, familiar to people (Siberian realism is hidden in this formula, which is the theme of the human resistance to harsh world, the contrast of the warmth of human and the coldness of being). Moonlight is cold, unknown (and therefore hidden by the mist), but inexplicably appealing, alluring up and deep.

Picture as if tells the audience: "Look first at the heavy snowdrifts, then go up the path to the twinkling lights of the windows, rise with the warm smoke from the chimneys, glance through the weightless icy mist to the cool, mysterious moon, go to what no one knows about, to the mysteries that lie beyond human life on the Earth.

For the current generation of urbanized viewers the work The Winter Motive after B.Ia. Riauzov is a kind of tale of the nineteenth century, and at the same time it updates the eternal question of man's place in this world and the issue of Siberian contrast.

The Winter Motive is close to one of the best works of B.Ia. Riauzov - The Slight Frost (1980), which is an example of a landscape painting, monumental collective image, painted on the basis of numerous sketches. Houses are set as the main characters. Riauzov's houses are always displayed together, playing the role of a social organism. Society, located between the heaven and the earth is like a legitimate mediator, as a child of both the first and the second. Landscape of "thaw" time has more freedom in the brushstrokes. The "stagnation" time (the most stable period of the Soviet history) is reflected in the frosty landscape where everything is veiled with frosty haze, and only lit windows of houses create tense and mystical dialogue with the luminary in the sky.

In general, we can say that the 1970-1980 period is the creation of many masterpieces of landscapes in B.Ia. Riauzov's museum. These landscapes are particularly stable, blissfully calm and a symbol of uneventfulness, which permeates fully into the artist's canvases.

The painting Karaulnaya Gora (Gora is the Russian for mountain) (1972), as well as most of B.Ia. Riauzov's works, is in horizontal format. The 


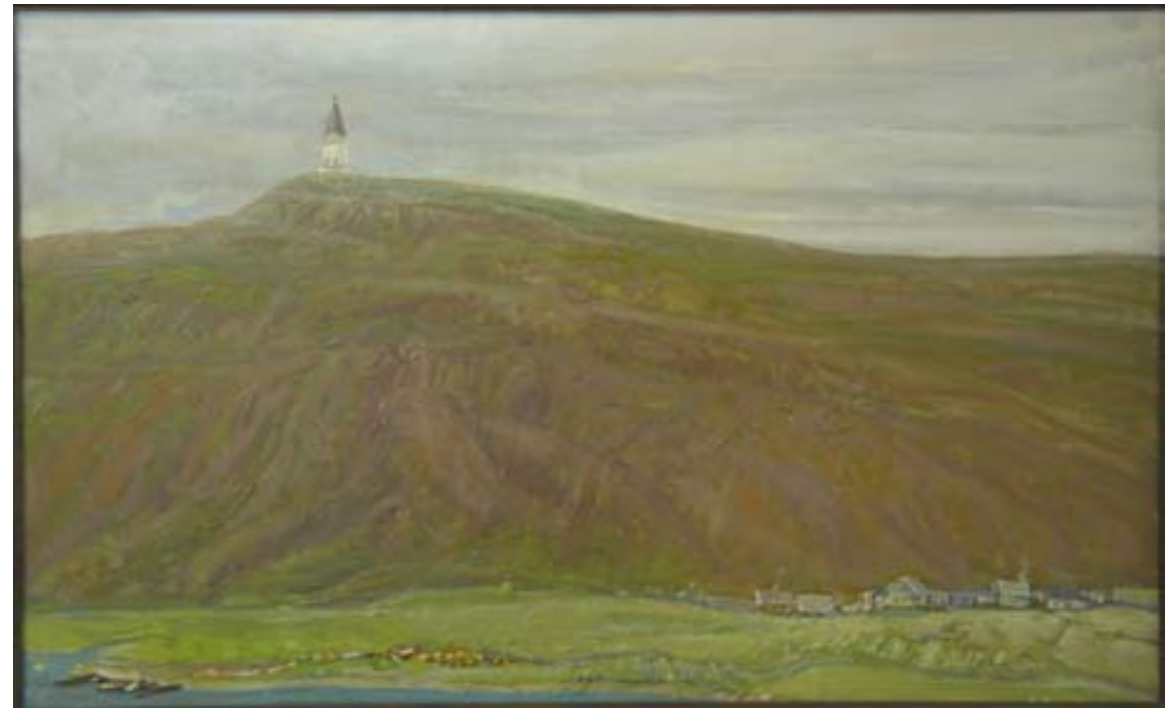

Pic. 4. Boris Riauzov. Karaulnaya Gora (1972)

painting deserves the attention because of warm color, unlike some B.Ia. Riauzov's landscapes of other kind, which represent the opposition between man and nature. The landscape Karaulnaya Gora simulates the relationship between culture and nature as organically related to each other sides of life, like equal partners in a dialogue. The character of strokes is remarkable, as they are different, depending on the object that they form, for example, the horizontal strokes are much longer than the vertical, at this very stage they embody the idea of the vast breadth of Siberian nature.

In this picture we see the landscape of Krasnoyarsk, which became a symbol of the city, Karaulnaya Gora with the Paraskeva Pyatnitsa Chapel. The chapel is presented as an organic completion of the mountain, its logical complement. A mountain range is majestic and powerful, and the chapel looks like a replica of human culture, thus harmonizing dialogue with nature.

It is noteworthy that the chapel is painted completely against the background of the celestial space, partly merging in its whiteness with white- gray, severe air. The mountain range, that has a stepped form, presents at its highest stage this work in the style of Russian steepled church as an offering to God. The lower part of the picture shows the world of the valley, which is a separate world, a layer of being distanced from the world above, the path to which lies along the folds of the hills of the steep ravine. In it there is flickering vain world, with wooden houses and boats on the river bank. However, these layers of being (the heavenly world, the world above, the earthly world) do not destroy the whole picture of the world, but rather connects it in the unity of the triad by the rhythm of take-off, which is gaining its momentum from the little houses on the hill to the steeple of the chapel. The slow rhythm emphasizes the difficulty of the way up the hill, not ease relations with the sky, the demand for the stresses and strains to reach the highest grace.

Among landscapes of B.Ia. Riauzov works showing the actively developing city of Krasnoyarsk are rather common. In his paintings, the artist captures new types of public buildings with documentary precision, while bringing in the urban image some kind of a philosophical 


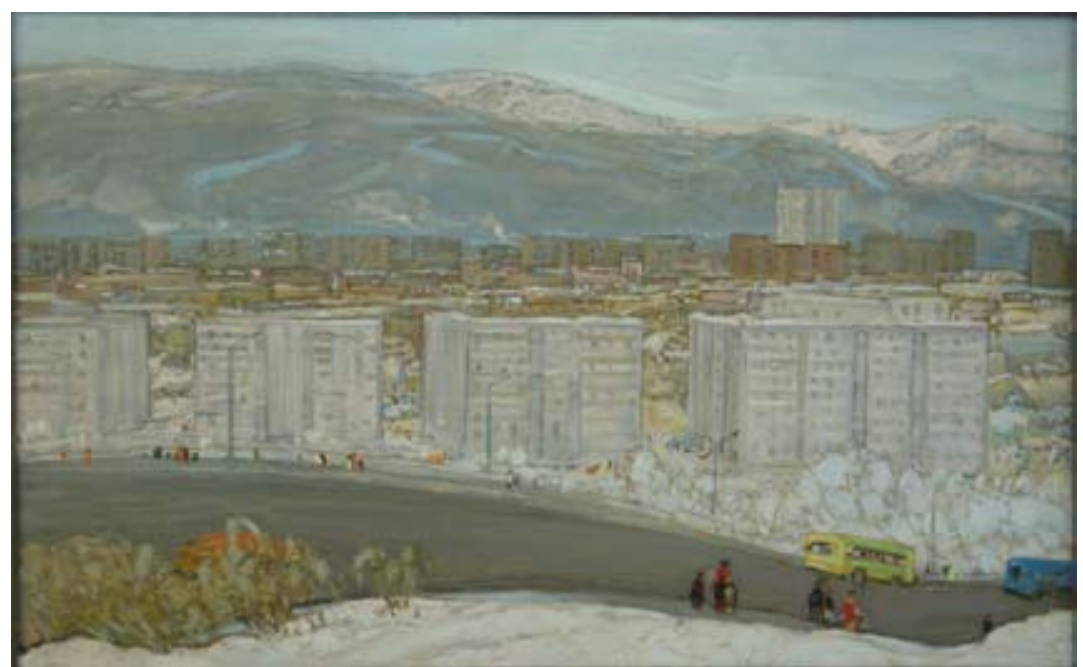

Pic. 5. Boris Riauzov. The City Is Being Built (1985)

note. In this regard, the work The City Is Being Built (1985) is opposed to the work A New Town. The Past Goes by.

New for that time in Siberia high apartment blocks are likened to the mountains of the painting's background, both in color and size. However, the selected point of view allows the artist to realize the true greatness of the mountainous area. Choosing a panoramic view, the artist as if elevates the viewers, allowing them to break away from the routine of the urban space and see the beautiful mountain ranges, which may have previously been hidden behind the houses. Portraying mountains, Riauzov also presents them in horizontal stretch, like a frieze. The competition of the layers in the city being built and lofty mountains alludes to the rise of the city to the mountains' level, which tradition has always understood as a symbol of high spirit. Nevertheless, the drawn line will not reach the world above, the city mundane space is the worldly space, therefore the road on which the buses and the people move is depicted as going down. People and buses are shown as descending, receding, leaving the hill characters. Layers reproduce the structure of the world: top, bottom and middle. What is presented here as a middle layer in the new buildings means an emphasis on sociocentric religion pathos, i.e. the renewal of life and daily routine.

Four works in B.Ia. Riauzov's museum Green Grass (1950), The Etude with a Red Roof (1958), Pink Mountain (1960) and The Long-awaited Spring (1968) were painted at different time. 18 years passed between the first and the last. More surprising is their exposure which emphasizes their integrity. These works can be attributed to one series: they are "chamber", have sketchy character, fragmentation and generalization. The human presence is indicated only in low rural buildings, so the human world scale becomes petty, simultaneously dissolving in nature.

In the paintings one can see the absence of any action, so the quality of time is lost. This is achieved by the refusal to paint the man himself, as a factor contributing to vanity in this world. Besides, the image of the very landscape with monumental forms of mountain ranges and virgin lands, elongated horizontal lines, make the painting still, peaceful and eternal.

Characters in these B.Ia. Riauzov's works are the sky, earth and human dwelling between 


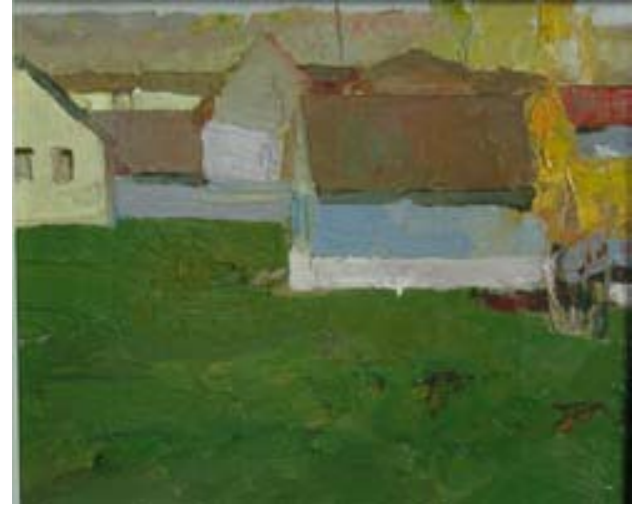

Pic. 6. Boris Riauzov. Green Grass (1950)

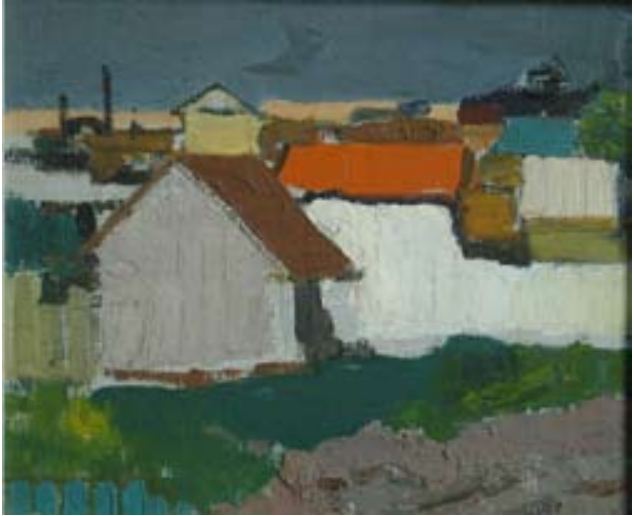

Pic. 7. Boris Riauzov. The Etude with a Red Roof (1958)

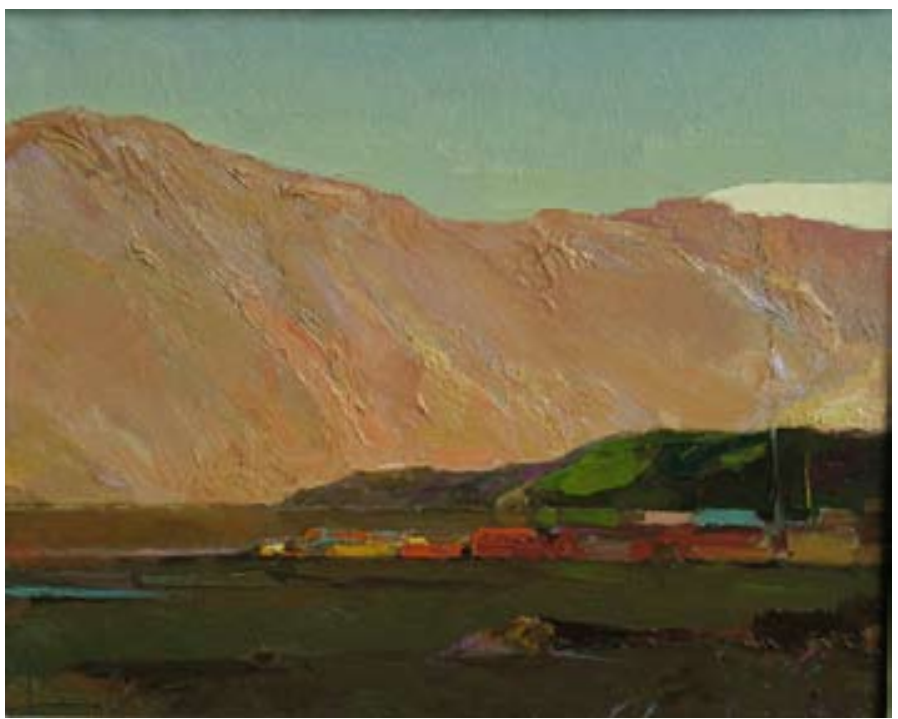

Pic. 8. Boris Riauzov. Pink Mountain (1960)

them. Vertical lines are almost absent. Only thin antennas' lines are directed here and there to the sky, but the main link between the heaven and the earth are gable roofs or mountains themselves. The artist interested in the earthly world to a larger extent, as the sky is represented by a narrow horizontal strip only, while $4 / 5$ surface of the painting are devoted to the earthly landscape. In these pictures it is possible to notice something archaic, thanks to the idea of human rootedness in their own land, as well as through pure and deep colors. The image of the naked earth, rich and ready to bear fruit, can be seen in Longawaited Spring.

This is the latest painting in this series and it probably shows the results of the artistic searches. Rejecting the streetscape, the painter gradually came to the standard of rural life, and afterwards he brought all human presence in nature to an end. Only then the revival of the land and the arrival of the long-awaited spring became possible. The theme of this revival is rooted in the 


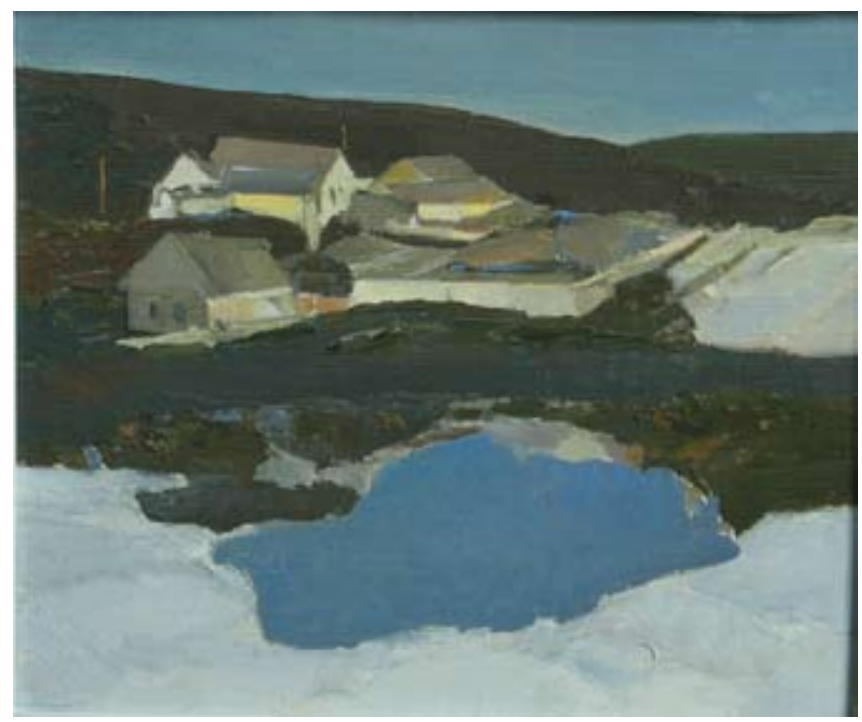

Pic. 9. Boris Riauzov. Long-awaited Spring (1968)

Russian climate, folklore and traditions of Russian landscapes. Color in B.Ia. Riauzov's works due to its depth becomes important. This color scheme corresponds to the land full with moisture (deep blue, juicy green, oily brown). The white color in showing snow or whitewashed dwellings is essential for the artist. Purity and whiteness of the snow are associated with spiritual purity of man living in harmony with nature in a rural idyll. The analogy of snow and water reproduces the relationship between spiritual purity and productive life.

The image which we see in the works to generalize, deprived of time. There is still historically specific connection: you can determine exactly what kind of land is shown, what are the people living there, but the general nature of the relationship between man and nature is more important, as it is harmonious and interdependent.

\section{Conclusion}

1. The researchers found two models of relationships between human (cultural origin) and the world (natural origin) in B.Ia. Riauzov's works. The first model is related to the mutual rejection, the second deals with harmony, love attraction of subjects to each other.

2. Representation of the first model (the conflict between human and the world) occurs primarily in the works of military theme, as well as in the theme of new and changing form of reality, technological progress, which breaks into the landscape. Consequently, a huge role in causing the conflict between human and the world shall be seen in the fruits of humanity itself, i.e. in the military actions and manmade hazards. It is necessary to recognize that B.Ia. Riauzov's means of showing the conflict are cold documentary and reportage realism style, composition (dominant horizontal lines, diagonal structures, cross-type intersections), Riauzov's painting style can be largely called a visual interpretation of the "lost generation" style, invented in the $20^{\text {th }}$ century by Ernest Hemingway, who is known for trying to say a lot through a small example, for example, the internal stress or psychological discomfort were described in his works in terse expressive means of language ("iceberg principle"). 
3. Representation of the second model is in the works, in which the idea of an isolated world is predominant, in which the upper and lower part are not opposed to each other, but instead they find some unity, dialogue with each other. In some works of this line there is clear (ternary) structure of the universe, while the mountain and earthly worlds have their own life, and also there is some intermediary zone in which they can freely enjoy intermixibility.
4. The relationship between human and the world thus functions as a means to study the specificity of landscape art. It helps to find a connection with the worldview models in culture, to expose the specifics of the landscape's certain time school. Provided further research in this area on the basis of the different artists of the landscape we can form a characteristic system of original landscape schools.

\section{References}

1. Gontarovskii, Ie. (1967). Boris Iakovlevich Riauzov (leaflet). Krasnoyarsk.

2. Koptseva, N. P. (2000). Modelirovanie tselostnosti v filosofskom poznanii [Modeling integrity in philosophical knowledge]. Bulletin of the Krasnoyarsk State University. Humanities. Krasnoyarsk, KSU.

3. Lomanova, T.M. 85 let so dnia rozhdeniia narodnogo khudozhnika RSFSR, chlenakorrespondenta AKh SSSR, lareata Gosudarstvennoi premii RSFSR B.Ia. Riauzova $\left[85^{\text {th }}\right.$ anniversary of the People's Artist of the RSFSR, Corresponding Member of the USSR Academy of Arts, laureate of the State Prize of the RSFSR B.Ia. Riauzova]. Our Krasnoyarsk Krai: Calendar of Significant and Memorable Dates for 2004, ed. by T.M. Lomanova, B.A. Chmykhalo. State Scientific Library of Krasnoyarsk Krai, 2003. Pp. 53-55.

4. Moskaliuk, M.V. (author and compiler). Vsio, chto v serdtse. Khudozhniki Krasnoiaria vchera, segodnia, zavtra. [All that is in the Heart. Krasnoyarsk Artists Yesterday, Today and Tomorrow]. Krasnoyarsk, Polikor, 2010.

5. Moskaliuk, M.V. Boris Riauzov. Painting: Album. Krasnoyarsk: Platina, 1999. 128 p.

6. Riauzov, B.Ia. Gorod glazami khudozhnika [City through the Eyes of the Artist]: Exhibition of B.Ia. Riauzov's works. Krasnoyarsk: Platina, 1998. 20 reproductions.

7. Riauzov, B.Ia. Painting: Exhibition Catalogue, 1919-1994. Krasnoyarsk: Platina, 1996. 44 p.

8. Riauzova, A. (2009). The Riauzovs. Family Collection: paintings. Krasnoyarsk: Promotion, 4 booklets.

9. Romanova, V. (project redactor and compiler), Rusakov, E. (2010). Maiskii val's, 1945: Krasnoiarskie khudozhniki v Velikoi Otechestvennoi voine [May Waltz, 1945: The Krasnoyarsk artists in the Great Patriotic War]. Krasnoyarsk, Krasnoyarsk regional branch of the Union of Artists of Russia, Romanov art-gallery.

10. Sarapkina, L.I. (compiler), Poliakova, M.A. (ed.). B.Ia. Riauzov. Krasnoyarsk, Krasnoyarsk Scientific library named after V.I. Lenin, 1979.

11. Shcherbakova, N.P., Muratov, K.S. (authors and compilers), Zommer, S.V. (photo). (2008) B.Ia. Municipal cultural institution Riauzov's Museum: a set of postcards. Chief Executive Department of Culture of Krasnoyarsk Krai Administration.

12. Zhukovskii, V.I. Teoriia izobrazitel'nogo iskusstva [Theory of Art]. Saint-Petersburg, 2011.

$$
-733-
$$




\section{Отношения человека и мира}

\section{в пейзажах Б.Я. Ряузова}

М.Г. Смолина, А.Н. Тамаровская, Д.В. Смирнова, Н.А. Федоряко, М.А. Легкова, Л.Н. Вергейчик, А.И. Татьянина Сибирский федеральньий университет Россия 660041, Красноярск, пр. Свободный, 79

В данной статье анализируется отношение человека и мира в живописном творчестве красноярского пейзажиста Б.Я. Ряузова. Авторы рассматривают две основнье мировоззренческие проблемы, отраженные в творчестве сибирского художника: конфликт «натуры» (первой природы) и «культурыл (второй природы, созданной человеком), идиллия отношения человека и мира.

Ключевые слова: живопись, Красноярск, Сибирь, Борис Яковлевич Ряузов, отночение человека и мира, пейзаж, социалистический реализм, Великая Отечественная война, горизонтальная композиичя, городской пейзаж, экзистенциальные проблемь.

Научная специальность: 24.00.00-культурология, 17.00.00-искусствоведение. 